\title{
33. RADIOLARIA FROM MEDITERRANEAN SEDIMENTS, DSDP LEG 42A
}

\author{
Annika Sanfilippo, Scripps Institution of Oceanography, La Jolla, California \\ J.-P. Caulet, Laboratoire de Géologie du Muséum National d'Histoire Naturelle, Paris \\ and \\ W.R. Riedel, Scripps Institution of Oceanography, La Jolla, California
}

\begin{abstract}
One radiolarian sample was obtained at each of Sites 376,378 , and 374 (this last not substantiated by all three authors), and a series of samples with less well preserved assemblages at Site 372 . The sample from Core 376-1 is Quaternary, and that from 378-8 (upper Pliocene) is younger than late Pliocene radiolarian samples from Crete. Cores 372-32 to approximately 372-41 may be equivalent to Mallorcan localities and Monte Calvo and Casalino in northern Italy, and Cores $372-42$ to $372-46$ may be equivalent to many other northern Italian Miocene radiolarian localities, but poor preservation and sparse assemblages at Site 372 preclude more precise correlation.
\end{abstract}

\section{INTRODUCTION}

No radiolarian specialist was included in the shipboard party of Leg $42 \mathrm{~A}$, and none participated in the post-cruise meetings. Consequently, this investigation was based on samples selected by specialists in calcareous microfossils, and the radiolarian results are not yet closely integrated with those from other fossil groups.

The localities of the drilling sites at which radiolarians were found are as follows:

Site $372: 40^{\circ} 01.86^{\prime} \mathrm{N}, 04^{\circ} 47.79^{\prime} \mathrm{E}$; water depth

2699 meters.

Site $374: 35^{\circ} 50.87^{\prime} \mathrm{N}, 18^{\circ} 11.78^{\prime} \mathrm{E}$; water depth

4078 meters.

Site $376: 34^{\circ} 52.32^{\prime} \mathrm{N}, 31^{\circ} 48.45^{\prime} \mathrm{E}$; water depth

2101 meters.

Site $378: 35^{\circ} 55.67^{\prime} \mathrm{N}, 25^{\circ} 06.97^{\prime} \mathrm{E}$; water depth

1835 meters.

All of the radiolarian assemblages obtained are of Miocene and younger ages, and our principal objective during this preliminary study has been to place them in the developing framework of Mediterranean Neogene stratigraphy. This having been done, they can be used in later studies directed toward reconstructing paleoenvironmental conditions in the Mediterranean.

\section{OCCURRENCES OF RADIOLARIANS}

The radiolarian occurrences are described in the following paragraphs and Table 1 . In the species lists and table, instead of using the uncalibrated terms "common", "few" and "rare" as in previous radiolarian chapters, we have determined the percentage abundances of selected species, relative to the total radiolarian assemblage coarser than $63 \mu \mathrm{m}$ and we present these numbers together with the total numbers of radiolarians on the slides examined. Thus these results can be evaluated quantitatively - which has obvious advantages as radiolarian stratigraphy progresses beyond its initial developmental and descriptive phase.

Site 372

One sample was examined from each of Cores 4 and 9 through 46 taken at this Site, but only those shown in Table 1 contained radiolarians. The assemblages were generally very sparse, and of moderate or poor preservation.

Site 374

Shipboard paleontologists found radiolarians in the catcher sample of Core 15, and forwarded them to one of us (J.-P.C.), who identified the following species here - ? Druppatractus irregularis, Carposphaera modesta (formerly Thecosphaera grecoi), Cyrtocapsella cayeuxi (Vinassa), Eucyrtidium elongatum (Stöhr), Heliodiscus asteriscus, H. echiniscus, Hexacontium sexaculeatum (formerly $H$. hootsi), Lithocampe eminens (Stöhr), L. fimbriata (Stöhr), L. radicula, Lychnocanoma grande, Ommatartus didymus, Stichocorys delmontensis, S. peregrina, Thecosphaera paroniana, and Trisulcus ?triloba.

There was too little time between the completion of arrangements for the writing of this chapter and the manuscript deadline, for the radiolarian slides to be sent from Paris to La Jolla. Therefore a new sample was obtained and examined (A.S. and W.R.) from Sample 374-15 CC. Although the sample was of several cubic centimeters, the only siliceous microfossil found in it was a single sponge spicule-no radiolarians nor diatoms were encountered.

\section{Site 376}

Only two samples from this Site were examined. That at $376-15-3,146-148 \mathrm{~cm}$, yielded no radiolarians, 
TABLE 1

Occurrences of Selected Species in Samples From Site 372

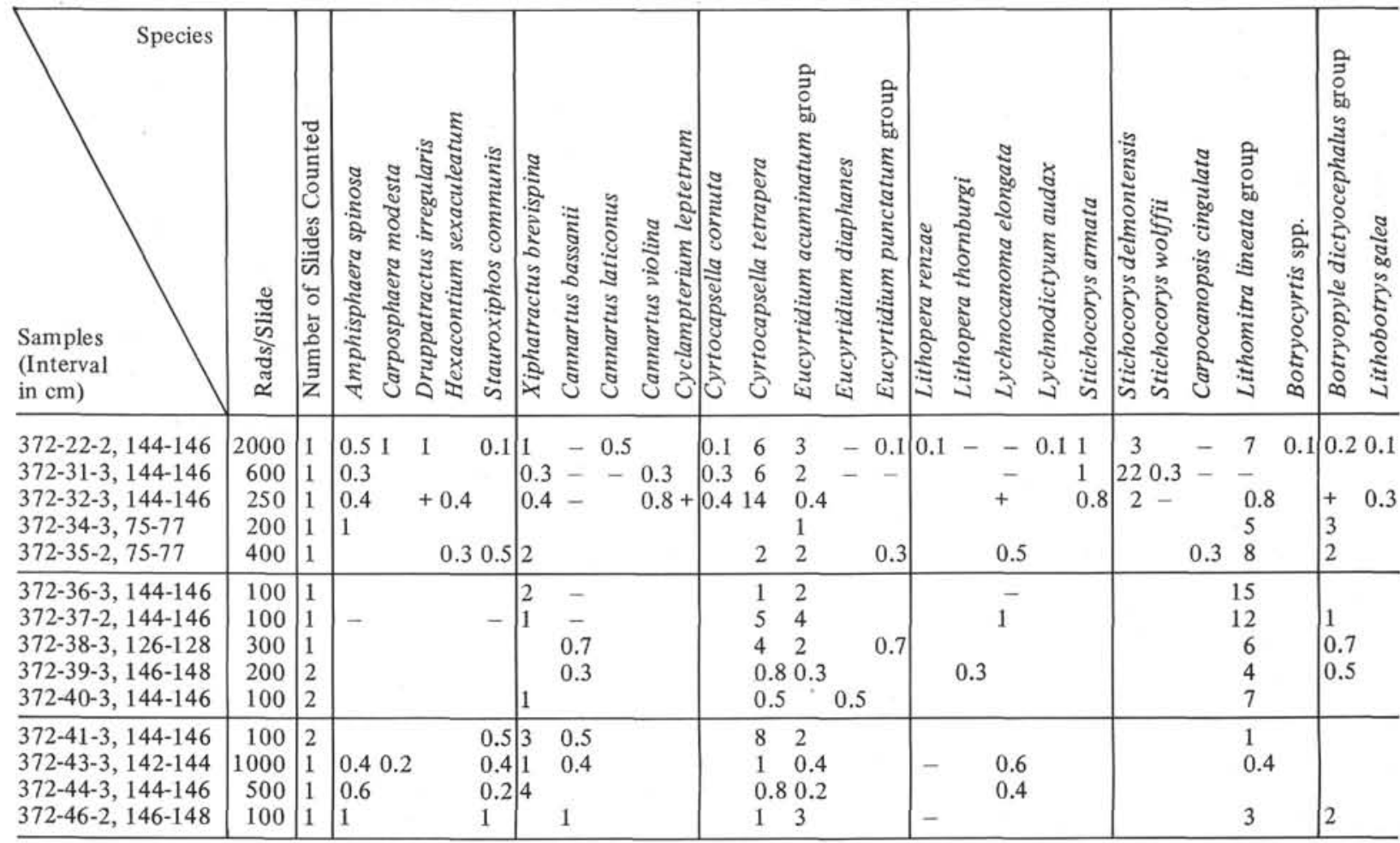

Note: Numbers in the body of the table are percentages of the total radiolarian assemblage. In cases where only one slide was examined closely without encountering a certain species, but that species was then found in examination of a supplementary slide, the occurrence is indicated as "+". Absences confirmed by close examination of two slides are indicated as "-.".

while that at $376-1-4,62-64 \mathrm{~cm}$, contained well preserved, abundant radiolarians (approximately 5,400 specimens per slide), including the following species with approximate percentage representation indicated - Hexacontium sexaculeatum (0.7\%), Druppatractus irregularis $(0.2 \%)$, Peripanartium sp. (1\%), Spongaster tetras $(0.5 \%)$, Nephrospyris renilla $(0.1 \%)$, Acanthodesmia vinculata $(0.5 \%)$, Eucyrtidium acuminatum group (2\%), E. anomalum (0.9\%), E. punctatum group (0.4\%), Siphocampe corbula $(0.2 \%)$, Botryocyrtis spp. $(0.3 \%)$, and Botryopyle dictyocephalus group $(0.2 \%)$. No specimens were found of Tholospyris rhombus, Pseudocubus vema, nor any species of Stichocorys..

\section{Site 378}

The only sample examined from this Site was Sample 8-1, 113-115 cm, where radiolarians are well preserved and common (approximately 2,800 specimens per slide). Species identified include the following, their approximate percentages of the total radiolarian assemblage being given in parentheses - Amphisphaera spinosa $(0.07 \%)$, Carposphaera modesta (0.6\%), Hexacontium sexaculeatum $(0.7 \%)$, Ommatartus didymus $(0.2 \%)$, Tholospyris rhombus $(0.4 \%)$, Eucyrtidium acuminatum group $(0.6 \%)$, Siphocampe corbula $(0.07 \%)$, Botryocyrtis sp. $(0.7 \%)$, Botryopyle dictyocephalus group (4.4\%), Lithobotrys galea $(0.7 \%)$, and Pseudocubus vema (3.3\%). No specimens were found of Druppatractus irregularis, Peripanartium sp., Eucyrtidium punctatum, nor any species of Stichocorys.

\section{STRATIGRAPHIC CORRELATIONS}

Figure 1 shows the correlations between radiolarian assemblages described here, and those known from other Mediterranean localities (for further details of which the reader is referred to the papers cited). The sample from Core 376-1 is Quaternary, and that from Core 378-8 (upper Pliocene on the basis of calcareous microfossils) is younger than late Pliocene radiolarian samples from Crete. Sample 374-15 CC has been examined by only one of us (J.-P.C.), and therefore its relationship to previously described Tabianian and Messinian assemblages is not yet firmly established. At Site 372 , where the only long sequence of radiolarian samples was obtained, Cores 32 to approximately 41 seem to be equivalent to Mallorcan localities and Monte Calvo and Casalino in northern Italy, and Cores 42 to 46 may be equivalent to many other northern Italian Miocene radiolarian localities (including those described by early authors such as Vinassa, 1900; Carnevale, 1908; and Lucchese, 1927), but more precise correlation is not possible because of poor preservation and sparse assemblages in the drilled cores.

\section{SPECIES LIST}

The purpose of this list is to provide bibliographic references to the taxa mentioned in this chapter, and some comments on their records in earlier literature. Unless otherwise indicated, we have rather uncritically followed the generic assignments applied by earlier authors, since shortage of time has prevented our examinirfg the relationships of type species of genera. 


\begin{tabular}{|c|c|c|}
\hline $\begin{array}{c}\text { Series } \\
\text { (and Stages) }\end{array}$ & 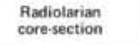 & Other Mediterranean Neogene radiolarian localities \\
\hline QUATERNARY & 376-1-1 & \\
\hline $\begin{array}{l}\text { UDPE' } \\
\text { PLIOCNE }\end{array}$ & 378.81 & \\
\hline \multirow{4}{*}{$\begin{array}{l}\text { upper MiOCENE } \\
\text { (Messinian) }\end{array}$} & \multirow{4}{*}{$374.15, \mathrm{cc}$} & Crete, late Pliocene (Sanfilippo and Riedel, 1975) \\
\hline & & Sicily, trubi, early Pliocene (Riedel et ol., 1974) \\
\hline & & N. Italy, Tabianian (Sanflilippo et all, 1973) \\
\hline & & Sicily, Torrente Rossi (Sanfilippo et al,, 1973) \\
\hline \multirow{2}{*}{$\begin{array}{l}\text { middle MIOCENE } \\
\text { (Langhian) }\end{array}$} & $372.22 \cdot 2$ & \\
\hline & $372 \cdot 31 \cdot 3$ & \\
\hline \multirow{13}{*}{$\begin{array}{l}\text { lower MiOCENE } \\
\text { (Burdigatian) }\end{array}$} & $372.32 \cdot 3$ & \multirow{5}{*}{ Mallorcan localities (Sanflitippo et all, 1973) } \\
\hline & $372 \cdot 34 \cdot 3$ & \\
\hline & 372.35 .2 & \\
\hline & $372 \cdot 36-3$ & \\
\hline & $372 \cdot 37 \cdot 3$ & \\
\hline & 372.38 .3 & \multirow[t]{3}{*}{ N. Italy - Monto Calvo and Casalino (Sanfilippo et al, 1973) } \\
\hline & 372.393 & \\
\hline & $\begin{array}{l}372-40-3 \\
372 \cdot 41 \cdot 3\end{array}$ & \\
\hline & $372-42 \cdot 3$ & \multirow{5}{*}{ 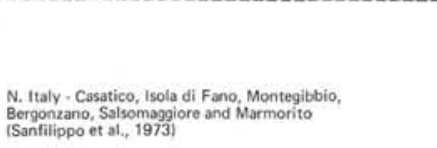 } \\
\hline & $372 \cdot 43 \cdot 3$ & \\
\hline & 372.443 & \\
\hline & $372-45 \cdot 3$ & \\
\hline & $372-46-2$ & \\
\hline
\end{tabular}

Figure 1. Correlations between Leg $42 \mathrm{~A}$ radiolarian samples and those from other Mediterranean Neogene localities. Most series and stage assignments are based on calcareous microfossils. Horizontal lines separate distinguishable assemblages.

There are also problems with many of the specific names, because several authors at the beginning of this century described Italian Neogene radiolarian assemblages, apparently directing more of their effort to the erection of new species than to critical comparisons with other described forms. Consequently, there are many synonyms in the literature. This is not the appropriate place to attempt to rectify the situation comprehensively, but we have clarified a few of the more obvious synonymies, on the basis of assemblages for which we have topotypic material available. A resulting inconvenience is that some familiar names such as Stylosphaera angelina become submerged as synonyms of species that themselves may be synonymized during later, more comprehensive work. However, such a period of confused nomenclature seems unavoidable if the existing unsatisfactory situation is to be improved.

Acanthodesmia vinculata (Müller, 1857, p. 484)

Synonymies and illustrations of this species are given by $\mathrm{Du}$ mitrica (1973) and Caulet (1974).

\section{Amphisphaera spinosa Carnevale, 1908, p. 14, pl. 2, fig. 6.}

This is the species that we have previously recorded as Stylosphaera angelina Campbell and Clark. Some specimens in our Sample WRE 67-100 (Sanfilippo, 1971) from Carnevale's locality Bergonzano have a thorny surface and others do not, the maximum diameter of the cortical shell is usually between 120 and $135 \mu$, and the two cylindro-conical polar spines vary in length and thickness. Therefore we are led to conclude that Doryconthidium isoacanthos Carnevale (1908, p. 12, pl. 1, fig. 7) and Stylosphaera isoporata Carnevale (1908, p. 13, pl. 2, fig. 3) are also synonyms.

The form that Stöhr $(1880$, p. 88 , pl. 1, fig. 12) recorded as Haliomma (Stylosphaera) hispidum Ehrenberg is evidently different from the form described by Ehrenberg (1854, pl. 36, fig. C26), but is likely the same as Amphisphaera spinosa.

Topotypic material of the radiolarian assemblage described by Principi is not available to us, but it seems likely that his species Amphistylus pantanellii Principi (1909, p. 7, pl. 1, fig. 16) is a synonym of this species.
Of the species described by Lucchese, Amphistylus rariporatus Lucchese (1927, p. 86, pl. 4, fig. 1) and Druppatractus microstylus Lucchese (1927, p. 93, pl. 5, fig. 9) have characters similar to Amphisphaera spinosa, but the dimensions given are much too large. However, the measurements she gives seem to be consistently too large (see Sanfilippo and Riedel, 1970, p. 452), and our examination of topotypic specimens from Sample WRE 67-107 (Sanfilippo, 1971) convinces us that these two species also are synonyms of the form under consideration.

In recent literature on Quaternary radiolarians, this species is commonly known as Stylatractus universus Hays (1970, p. 215, pl.1, fig. 1, 2)-as was pointed out by Kling (1973, p. 634).

\section{Botryocyrtis Ehrenberg (1860) spp.}

Members of this genus have previously been recorded from Mediterranean Neogene localities by Sanfilippo et al. (1973). A lumbar stricture is commonly well developed in specimens from Cores $376-1$ and $378-8$.

\section{Botryopyle dictyocephalus (Haeckel) group}

This group has previously been recorded from the Mediterranean Neogene by Sanfilippo et al. (1973).

Cannartus bassanii (Carnevale, 1908, p. 21, pl. 3, fig. 12)

The possible synonyms of this species have been determined by Sanfilippo et al. (1973, p. 216).

Cannartus laticonus Riedel, 1959, p. 291, pl. 1, fig. 5.

This species has previously been recorded from the Mediterranean Neogene by Sanfilippo et al. (1973).

Cannartus violina Haeckel, 1887, p. 358, pl. 39, fig. 10.

Other occurrences of this species in the Mediterranean Neogene are given by Sanfilippo et al. (1973).

Carpocanopsis cingulata Riedel and Sanfilippo, 1971, p. 1597, pl. 2G, fig. 17-21; pl. 8, fig. 8 .

A possible synonym is Cyrtocalpis tubulosa Vinassa (1900, p. 580 , pl. 2, fig. 25), but the original illustration is inadequate and we have been unable to examine topotypic material.

\section{Carposphaera modesta (Stör, 1880, p. 86, pl. 1, fig. 5).}

This species, described in the genus Haliomma by Stöhr and transferred to Carposphaera by Haeckel $(1887$, p. 74$)$, appears to be the same as that which we (Riedel et al. 1974, p. 707, pl. 56, fig. 3; pl. 62, fig. 2-4) have previously reported as Thecosphaera grecoi Vinassa (1900, p. 568, pl. 1, fig. 8). We have examined specimens from Messinian diatomites collected by M. N. Bramlette near Raddusa and Serradifalco, Sicily, and find no substantial difference from Vinassa's species.

We have earlier synonymized Thecosphaera leptococcos Carnevale (1908, p. 9, pl. 1, fig. 10) with this species. It also seems probable that Thecosphaera saccoi Principi (1909, p. 4, pl. 1, fig. 6) is a synonym, but we have not topotypic material available to check this.

Another possible synonym is Thecosphaera raripora Lucchese (1927, p. 82, pl. 3, fig. 5), and in order to check this we have examined topotypic material from $\mathrm{Ca}$ ' Lombasini (Sample WRE 67107 , see Sanfilippo, 1971). However, we have not found any specimens corresponding to the original description in having wellseparated pores and a single medullary shell, and thus the status of that species remains in doubt.

There is some similarity with the form from Caltanisetta, Sicily, described by Ehrenberg (1844, p. 83; 1854, pl. 22, fig. 35) as Haliomma aequorea, but the dimensions given (diameter $68 \mu$ according to the description) are too small.

Cyclampterium leptetrum Sanfilippo and Riedel, 1970, p. 456, pl. 2, fig. 11, 12.

This species has previously been recorded from Mediterranean localities by Sanfilippo et al. (1973).

Cyrtocapsella cornuta Haeckel, 1887, p. 1513, pl. 78, fig. 9. (1970).
Synonyms of this species are listed by Sanfilippo and Riedel 
Cyrtocapsella tetrapera Haeckel, 1887, p. 1512, pl. 78, fig. 5. (1970).

The synonymy of this species is given by Sanfilippo and Riedel

Druppatractus irregularis Popofsky, 1912, p. 114, text-fig. 24-26.

The early literature on Italian Neogene radiolarians does not seem to include this form.

Eucyrtidium acuminatum (Ehrenberg, 1844, p. 84) group

We have previously recorded these forms (Sanfilippo et al., 1973) as the Eucyrtidium cienkowskii Haeckel group, but there seems to be no justification for excluding the species described earlier by Ehrenberg, the name of which therefore has priority. Another member of this group is Dictyomitra caltanisettae Dreyer (1890, p. 48, pl. 6, fig. 31)-specimens which we have found in samples from Serradifalco and Raddusa closely resemble Stöhr's (1880, pl. 4, fig. 6) illustration of E. acuminatum. Specimens from older assemblages tend to have a pronounced stricture and change in contour between the second and third segments, as in Dictyomitra multicostata [sic!] Lucchese (1927, p. 106, pl. 8, fig. 8), Eucyrtidium sp. (ex gr. E. cienkowskii) of Bachmann et al. (1963, p. 130, pl. 8, fig. 37), and possibly Stichocorys martellii Principi (1909, p. 16, pl. 1, fig. 51).

Eucyrtidium anomalum (Haeckel, 1860, p. 839) (Plate 1, Figures 1, 2)

Possible synonyms of this species are listed by Dumitrica (1973) and Caulet (1974). It is distinguished from the $E$. punctatum group by its larger size and the presence of distinct wings on the thorax.

Eucyrtidium diaphanes Sanfilippo and Riedel in Sanfilippo et al., 1973 , p. 221 , pl. 5 , figs. $12-14$.

The taxonomy of this species, which occurs rarely in Samples WRE 67-99 and 67-100 (Sanfilippo, 1971), was adjusted in Sanfilippo et al. (1973). The same form occurs in Sample WRE 67-106 from Ca' de Rossi, but we did not find it in the sparse assemblage in WRE 67-107 from Ca' Lombasini, which is the type locality for Calocyclas coronata ( = Eucyrtidium diaphanes) globosa Lucchese (1927, p. 105, pl. 8, fig. 1) a probable synonym.

\section{Eucyrtidium punctatum (Ehrenberg, 1844, p. 84) group (Plate 1, Figure 3)}

The synonymy of this group is indicated in Sanfilippo et al. (1973). In addition to the records by Ehrenberg and Vinassa, Stöhr (1880) records Dictyomitra punctata Ehrenberg from presumably Messinian sediments of Sicily. Dumitrica (1973, p. 839, pl. 24, fig. 10 and, doubtfully, fig. 11) records the same form under the name Lithocampe heptacola Haeckel. Specimens in older assemblages tend to have longitudinal ribs separating rows of pores (see Sanfilippo et al., 1973, pl. 5, fig. 16).

Hexacontium sexaculeatum (Stöhr, 1880, p. 87, pl. 1, fig. 8)

This species, originally described in the genus Haliomma and transferred by Haeckel (1887) to Hexalonche, is here assigned to Hexacontium because the medullary shell is double, rather than single as indicated by Stöhr, in specimens that we have found to occur rarely in Messinian samples from Raddusa and Serradifalco, Sicily. We use this name for forms with cortical shell diameter 95$135 \mu$, which we have previously (Riedel et al. 1974, p. 705, pl. 54, fig. 4-6; pl. 61, fig. 9) recorded as Hexacontium hootsi Campbell and Clark (now regarded as a junior synonym). Other synonyms are Hexacontium multiporum Vinassa (1900, p. 571, pl. 1, fig. 26) and Stauracontium cameranii Carnevale (1908, p. 15, pl. 2, fig. 10, which on re-examination proves to have six spines), both of which we have found in samples from their type localities (WRE 67-96, 67-99, and 67-100, respectively, of Sanfilippo, 1971).

Lithobotrys galea Ehrenberg, 1844, p. 83. (Plate 1, Figures 4, 5)

In order to try to determine the nature of the cannobotrythid that Ehrenberg unsatisfactorily illustrated under this name, we have searched through assemblages of Messinian radiolarians from near
Raddusa and near Serradifalco, Sicily. Only in the sample from Raddusa (M. N. Bramlette sample no. 3 ) did we find any members of this family, and all were small forms with antecephalic and eucephalic chambers of approximately the same size, and a very small, indistinct postcephalic chamber.

Core 378-8 contains, in addition to members of the Botryopyle dictyocephalus group and Botryocyrtis sp., many specimens apparently assignable to $L$. galea some of which have a slightly enlarged and apically pointed antecephalic chamber.

\section{Lithomitra lineata (Ehrenberg) group Riedel and Sanfilippo} $(1971$, p. 1600) sensu lato

We here include in this group also those forms separated as Lithomitra sp. aff. L. lineata group by Riedel and Sanfilippo (1971, p. 1600 , pl. 1I, fig. 12; pl. 2I, fig. 17 ; pl. 3E, fig. 15-19). Probable members of this group in the Mediterranean Neogene include Lithomitra embrionalis Vinassa (1900, p. 586, pl. 3, fig. 21) and Lithomitra laevigata Principi (1909, p. 17, pl. 1, fig. 55).

Lithopera renzae Sanfilippo and Riedel, 1970, p. 454, pl. 1, figs. 21-23, 27.

This species has previously been recorded from Mallorca by Sanfilippo et al. (1973).

Lithopera thornburgi Sanfilippo and Riedel, 1970, p. 455, pl. 2, figs. 4-6.

Lychnocanoma elongata (Vinassa, 1900, p. 243, pl. 2, fig. 31).

The synonymy of this species has been clarified by Sanfilippo et al. (1973).

Lychnodictyum audax Riedel, 1953, p. 810, pl. 85, fig. 9.

This species occurs also in the late Pliocene of Crete (Sanfilippo and Riedel, 1975).

Nephrospyris renilla Haeckel, 1887, p. 1101, pl. 90, figs. 9, 10.

Ommatartus didymus (Ehrenberg, 1844, p. 83).

Specimens occurring in DSDP core 378-8 rarely have caps better developed than in the original illustration of Ommatocampe trinacria Stöhr (1880, p. 90 , pl. 2, fig. 1), which species was synonymized with O. didymus by Sanfilippo et al. (1973, p. 216).

\section{Peripanartium sp. \\ (Plate 1, Figure 6)}

This form is the same as that recorded from late Pliocene sediments of Crete by Sanfilippo and Riedel (1975, p. 66, pl. 1, figs. 5-7). It may be significant that this form has not been recorded in more westerly Mediterranean localities.

\section{Pseudocubus vema (Hays, 1965, p. 176, pl. 2, fig. 3, text-fig. A)}

This species has previously been recorded from the Mediterranean Neogene by Dumitrica (1973) and Sanfilippo and Riedel (1975).

Siphocampe corbula (Harting, 1863, p. 12, pl. 1, fig. 21).

This species occurs in Cores 376-1 and 378-8, those in the latter core being well developed except for the lack of a peristome. Its precursor (Riedel and Sanfilippo, 1971, p. 1601, pl. 1H, fig. 28) occurs in Core 372-22.

\section{Spongaster sp (p) \\ (Plate 1, Figures 7-9)}

The assemblage in Core 376-1 contains specimens of Spongaster conforming morphologically to several different species (S. tetras, $S$. pentas and $S$. berminghami), so that we have not been able to determine satisfactorily which species is present. The situation here is analogous to that described by Riedel and Sanfilippo (in press, fig. 2, and pl. 2) for the assemblages in DSDP Hole 77B prior to the establishment of $S$. berminghami and between $S$. berminghami and S. tetras. 
A single specimen closely resembling $S$. tetras was found anomalously in the sample from Core $372-38$ (see also Riedel and Sanfilippo, 1971, pl. 5, fig. 1, for a similar early Miocene record).

Stauroxiphos communis Carnevale, 1908, p. 15, pl. 2, fig. 9, (Plate 1, Figure 10)

Specimens from Site 372 agree well with the original description and illustration, except that they have more than three radial bars prolonged as short spines, and the medullary shell is pear-shaped. In order to check their identity with topotypic material, we have examined the radiolarian assemblage in Sample WRE 67-100 (Sanfilippo, 1971) and find that specimens there have the characters of those in the Leg 42 specimens.

It seems likely that Stauroxiphos sexradiatus Lucchese (1927, p. 86 , pl. 4, fig. 3) is a synonym, despite the puzzling description of the pores of the cortical shell as less numerous. We have examined topotypic material of this species from Ca' Lombasini (Sample WRE 67-107, Sanfilippo, 1971), and find that the pores of the cortical shell are similar to those of Carnevale's species.

Stichocorys armata (Haeckel, 1887, p. 1460, pl. 78, fig. 17)

The possible synonymy of this species has been discussed by Sanfilippo et al. (1973).

Stichocorys delmontensis (Campbell and Clark, 1944, p. 56, pl. 7, figs. 19-21)

Possible synonyms of this species are indicated by Sanfilippo and Riedel (1970).

\section{Stichocorys peregrina (Riedel, 1953, p. 812, pl. 85, fig. 2)}

This species has been recorded also from the stratotype Zanclean (Riedel et al., 1974), and from the late Pliocene of Crete (Sanfilippo and Riedel, 1975).

Stichocorys wolffii Haeckel, 1887, p. 1479, pl. 80, fig. 10

We have not previously found this species in the Mediterranean Neogene.

Tholospyris rhombus (Haeckel, 1887, p. 942, pl. 81, fig. 7)

This species, emended by Goll (1972), has been recorded by Sanfilippo and Riedel (1975) from the late Pliocene of Crete.

Trigonastrum regulare Haeckel, 1887, p. 539, pl. 43, fig. 16, (Plate 1, Figure 11)

This distinctive species, recorded by Dumitrica (1973) from DSDP Core 128-3, occurs also in Core 276-1, and in order to elucidate its occurrence we have searched through the other late Neogene samples from the Mediterranean region available to us. $T$. requlare was not found in any of them, and only one (Sample 767A from Pigi, Crete - see Sanfilippo and Riedel, 1975) contained rare specimens assignable to the species that Dumitrica (1973) identified as Amphirhopalum wirchowii and that Nigrini (1971) recorded as A. ypsilon. This latter species occurs also in Cores 376-1 and 378-8.

Xiphatractus brevispina Carnevale, 1908, p. 20, pl. 3, fig. 11, (Plate 1, Figures 12, 13)

The Leg 42 specimens conform sufficiently well with Carnevale's description and illustration to justify this identification, but some deviations need to be noted. Our specimens are not well enough preserved to determine whether the pores of the second shell are larger than those of the outer shell. Also, the original description indicates that the polar spines are short, and that only one is bladed. We have examined specimens of this species in topotypic material (Sample WRE 67-100, see Sanfilippo, 1971) and find that the polar spines there vary from being so short that distinction between bladed and conical form is uncertain, to both being longer than originally illustrated and distinctly bladed.

\section{ACKNOWLEDGMENTS}

Financial support for part of this study was provided by NSF Grant OCE75-10275. M. A. Hanger competently typed the manuscript, and P. B. Helms assisted with the proofreading.

\section{SPECIES INDEX}

Although this paper is short, an index seems desirable because so many synonymies are suggested. Specific names are arranged alphabetically, with generic names secondary.

acuminatum group, Eucyrtidium, 4, 12, Table 1

aequorea, Haliomma, 11

angelina, Stylosphaera, 8

anomalum, Eucyrtidium, 4, 12, Plate 1, Figures 1, 2

armata, Stichocorys, 17, Table 1

asteriscus, Heliodiscus, 3

audax, Lychnodictyum, 14, Table 1

bassanii, Cannartus, 10, Table 1

berminghami, Spongaster, 16

Botryocyrtis spp., 4, 9, 14, Table 1

brevispina, Xiphatractus, 18, Table 1, Plate 1, Figures 12, 13

caltanisettae, Dictyomitra, 12

cameranii, Stauracontium, 13

cayeuxi, Cyrtocapsella, 3

cienkowskii group, Eucyrtidium, 12

cingulata, Carpocanopsis, 10, Table 1

communis, Stauroxiphos, 16, Table 1, Plate 1, Figure 10

corbula, Siphocampe, 4, 15

cornuta, Cyrtocapsella, 11, Table 1

coronata globosa, Calocyclas, 13

delmontensis, Stichocorys, 3, 17, Table 1

diaphanes, Eucyrtidium, 12, Table 1

dictyocephalus group, Botryopyle, 4, 10, 14, Table 1

didymus, Ommatartus, 3, 4, 15

echiniscus, Heliodiscus, 3

elongata, Lychnocanoma, 15, Table 1

elongatum, Eucyrtidium, 3

embrionalis, Lithomitra, 14

eminens, Lithocampe, 3

fimbriata, Lithocampe, 3

galea, Lithobotrys, 4, 14, Table 1, Plate 1, Figures 4, 5

grande, Lychnocanoma, 3

grecoi, Thecosphaera, 3, 10

heptacola, Lithocampe, 13

hispidum, Haliomma, 9

hootsi, Hexacontium, 3, 13

irregularis, Druppatractus, 3, 4, 12, Table

isoacanthos, Doryconthidium, 9

isoporata, Stylosphaera, 9

laevigata, Lithomitra, 14

laticonus, Cannartus, 10, Table 1

leptetrum, Cyclampterium, 11, Table 1

leptococcos, Thecosphaera, 11

lineata group, Lithomitra, 14, Table 1

martellii, Stichocorys, 12

microstylus, Druppatractus, 9

modesta, Carposphaera, 3, 4, 10, Table 1

modesta, Haliomma, 10

multicostata, Dictyomitra, 12

multiporum, Hexacontium, 13

pantanellii, Amphistylus, 9

paroniana, Thecosphaera, 3

pentas, Spongaster, 16

peregrina, Stichocorys, 3, 17

Peripanartium sp., 4, 15, Plate 1, Figure 6

punctata, Dictyomitra, 13

punctatum group, Eucyrtidium, 4, 12, 13, Table 1, Plate

1, Figure 3

radicula, Lithocampe, 3

raripora, Thecosphaera, 11

rariporatus, Amphistylus, 9

regulare, Trigonastrum, 17, Plate 1, Figure 11

renilla, Nephrospyris, 4, 15

renzae, Lithopera, 14, Table 1

rhombus, Tholospyris, 4, 17

saccoi, Thecosphaera, 11 
sexaculeatum, Hexacontium, 3, 4, 13, Table 1

sexradiatus, Stauroxiphos, 16

spinosa, Amphisphaera, 4, 8, 9, Table 1

Spongaster sp., 16, Plate 1, Figures 7, 9

tetrapera, Cytrocapsella, 11, Table 1

tetras, Spongaster, 4, 16

thornburgi, Lithopera, 14, Table 1

triloba, Trisulcus, 3

trinacria, Ommatocampe, 15

tubulosa, Cyrtocalpis, 10

universus, Stylatractus, 9

vema, Pseudocubus, 4, 15

vinculata, Acanthodesmia, 4, 8

violina, Cannartus, 10, Table 1

wirchowil, Amphirhopalum, 17

wolffii, Stichocorys, 17, Table 1

ypsilon, Amphirhopalum, 17

\section{REFERENCES}

Bachmann, A., Papp, A., and Stradner, H., 1963. Mikropalaontologische Studien im "Badener Tegel"' von Frattingsdorf N.Ö: Mitt. Geol. Gesell. Wien, v. 56, p. 117-210.

Campbell, A. S. and Clark, B. L., 1944. Miocene radiolarian faunas from southern California: Geol. Soc. Amer., Spec. Paper, no. 51, p. 1-76.

Carnevale, P., 1908. Radiolarie e silicoflagellati di Bergonzano (Reggio Emilia): R. Ist Veneto Sci. Lett. Arti. Mem., v. 28, p. 1-46.

Caulet, J.-P., 1974. Les Radiolaires des boues superficielles de la Méditerranée: Bull. Mus. National Hist. Naturelle, ser. 3 , no. 249 , Sciences de la Terre 39 , p. 217-288.

Dreyer, F., 1890. Die Tripoli von Caltanisetta (Steinbruch Gessolungo) auf Sizilien: Jenaischen Zeitschr. Naturwiss., v. 24 , n. ser. 17 , p. $471-548$.

Dumitrica, P., 1973. Cretaceous and Quaternary radiolaria in deep sea sediments from the northwest Atlantic Ocean and Mediterranean Sea. In Ryan, W. B. F., Hsü, K. J., et al., Initial Reports of the Deep Sea Drilling Project, Volume 13: Washington (U.S. Government Printing Office), p. 829-901.

Ehrenberg, C. G., 1844. Über 2 neue Lager von Gebirgsmassen aus Infusorien als Meeres-Absatz in Nord-Amerika und eine Vergleichung derselben mit den organischen Kreide-Gebilden in Europa und Afrika: K. Preuss. Akad. Wiss. Berlin, Ber., Jahrg. 1844, p. 57-97.

1854. Mikrogeologie. Leipzig: Voss, xxviii +374 p., Atlas, 31 p., 41 pls. Fortsetzung (1856), 88 p. +1 p. errata.

1860. Über den Tiefgrund des stillen Oceans zwischen Californien und den Sandwich-Inseln aus bis 15600' Tiefe nach Lieut. Brooke: K. Preuss, Akad. Wiss. Berlin, Monatsber., Jahrg. 1860 , p. $819-833$.

Goll, R. M., 1972. Systematics of eight Tholospyris taxa (Trissocyclidae, Radiolaria): Micropaleontology, v. 18, p. 443-475.

Haeckel, E., 1860. Fernere Abbildungen and Diagnosen neuer Gattungen und Arten von lebenden Radiolarien des Mittelmeeres: Kgl. Preuss. Akad. Wiss. Berlin, Monatsber., Jahre 1860 , p. $835-845$

1887. Report on the radiolaria collected by H. M S. Challenger during the years 1873-76: Rept. Voyage Challenger, Zool., v. 18.

Harting, P., 1863. Bijdrage tot de kennis der mikroskopische fauna en flora van de Banda-Zee: Koninkl. Akad. Wetenschap. Amsterdam, Verh. 10, p. 1-34, pls. 1-3.

Hays, J. D., 1965. Radiolaria and late Tertiary and Quaternary history of Antarctic seas: Biol. Antarctic Seas, v. 2, Antarctic Res. Ser. 5 (Am. Geophys. Union), p. 125-184.
1970. Stratigraphy and evolutionary trends of radiolaria in North Pacific deep-sea sediments: Geol. Soc. Am. Mem. 126, p. 185-218.

Kling, S. A., 1973. Radiolaria from the eastern North Pacific, Deep Sea Drilling Project Leg 18. In Kulm, L. D., von Huene, R., et al., Initial Reports of the Deep Sea Drilling Project, Volume 18: Washington (U.S. Government Printing Office) p. 617-671.

Lucchese, C., 1927. Radiolari miocenici di Salsomaggiore: Giorn. Geol., ser. 2, v. 2, p. 80-116.

Müller, J., 1857. Über die Thalassicollen, Polycystinen und Acanthometren des Mittelmeeres: Kgl. Preuss. Akad. Wiss. Berlin, Monatsber., Jahre 1856, p. 474-503.

Nigrini, C. A., 1971. Radiolaria zones in the Quaternary of the equatorial Pacific Ocean. In Funnell, B. M. and Riedel, W. R., (eds.), The micropaleontology of oceans: Cambridge (Cambridge Univ. Press), p. 443-461.

Popofsky, A., 1912. Die Sphaerellarien des Warmwassergebietes: Deutsche Südpolar-Exped. 1901-1903, v. 13 (Zool. v. 5), p. 73-159, Berlin.

Principi, P., 1909. Contributo allo studio dei Radiolari Miocenici Italiani: Soc. Geol. Ital., Boll., v. 28, p. 1-22.

Riedel, W. R., 1953. Mesozoic and late Tertiary radiolaria of Rotti: Jour. Paleontol., v. 27, p. 805-813. 1959. Oligocene and lower Miocene radiolaria in tropical Pacific sediments: Micropaleontology, v. 5, p. 285-302.

Riedel, W. R., and Sanfilippo, A., 1971. Cenozoic radiolaria from the western tropical Pacific, Leg 7. In Winterer, E. L. et al., Initial Reports of the Deep Sea Drilling Project, Volume 7: Washington (U.S. Government Printing Office), p. 1529-1672.

(in press). Stratigraphy and evolution of tropical Cenozoic radiolarians: Symposium "Marine Plankton and Sediments”, Kiel (Micropaleontology Press, Amer. Mus. Nat. Hist., New York).

Riedel, W. R., Sanfilippo, A., and Cita, M. B., 1974. Radiolarians from the stratotype Zanclean (lower Pliocene, Sicily): Riv. Ital. Paleont., v. 80 , p. 699-733.

Sanfilippo, A., 1971. Neogene radiolarians of the Mediterranean and western Pacific. In Farinacci, A., Ed., Proceedings of the II Planktonic Conference, Roma, 1970: Rome (Edizioni Tecnoscienza), v. 1, p. 1121-1127.

Sanfilippo, A. and Riedel, W. R., 1970. Post-Eocene "closed"' theoperid radiolarians: Micropaleontology, v. 16 , p. $446-462$.

Sanfilippo, A., Burckle, L. H., Martini, E., and Riedel, W. R., 1973. Radiolarians, diatoms, silicoflagellates and calcareous nannofossils in the Mediterranean Neogene: Micropaleontology, v. 19, p. 209-234.

1975. Late Tertiary radiolarians from Crete: Proc. VI Congress Regional Committee on Mediterranean Neogene Stratigraphy, Bratislava 1975, p. 61-74.

Stöhr, E., 1880. Die Radiolarienfauna der Tripoli von Grotte, Provinz Girgenti in Sicilien: Paleontographica, v. 26 (ser. 3 , v. 2), p. 69-124.

Vinassa de Regny, P. E., 1900. Radiolari Miocenici Italiani: R. Accad. Sci. Ist. Bologna Mem., ser. 5, v. 8, p. 565-595.

\section{ADDENDUM}

Since this paper was completed, Sanfilippo and Riedel have been able to examine four of Caulet's slides of Sample 374-15, CC. On these slides they have encountered Carposphaera modesta ( 9 specimens); unidentified actinommids (8); Cannartus petterssoni 
(one fragment, but unambiguously identifiable); Peripanartium sp. (1); phacodiscids (3); spongodiscids and porodiscids (34); pyloniids (5); litheliids (2); Cyrtocapsella japonica, which may be equivalent to Theocapsa cayeuxi Vinassa (1); Eucyrtidium acuminatum group (1); Stichocorys delmontensis (8); unidentified theoperids (5); incertae sedis (1); and two specimens evidently reworked from Cretaceous (one Dictyomitra sp. and one Sethocapsa sp.)-total of 81 specimens.

The presence of Cannartus petterssoni indicates the late middle Miocene $C$. petterssoni Zone, and presumably if Stichocorys peregrina morphotypes occur on other slides they are greatly subordinate to $S$. delmontensis morphotypes.

\section{PLATE 1}

(In the figure explanations, the sample numbers and slide designations in the form "Ph.2", "Sl.1", etc. indicate preparations in our collection, and designations in the form "R $45 / 1$ " indicate England Finder positions of the illustrated specimens on the slides.)

Figures 1, 2 Eucyrtidium anomalum.

1. 376-1-4, 62-64 cm, Ph.2, O48/2, $280 \times$.

2. Same slide, V30/4, $280 \times$.

Figure 3 Eucyrtidium punctatum group.

376-1-4, 62-64 cm, Ph.2, Y26/0, 280×.

Figures 4, 5 Lithobotrys galea.

4. 372-22-2, 144-146 cm, Sl.1, F43/0, 280X.

5. 378-8-1, 113-115 cm, F.1, W41/4, 280X.

Figure 6 Peripanartium sp.

376-1-4, 62-64 cm, Cs.1, Z54/3, 280X.

Figures 7-9 Spongaster sp.

7. 376-1-4, 62-64 cm, Cs.1, J43/2, $190 \times$.

8. Same slide, F41/0, $190 \times$.

9. Same slide, J24/3, 190X.

Figure 10 Stauroxiphos communis.

372-22-2, 144-146 cm, S1.2, D30/1, 280×.

Figure 11 Trigonastrum regulare.

376-1-4, 62-64 cm, Cs.1, 050/0, 190×.

Figures 12, 13 Xiphatractus brevispina.

12. 372-44-3, 144-146 cm, Sl.2, Q15/2, 280×.

13. Same slide, $\mathrm{L} 22 / 4,280 \times$.

(see p. 760 ) 
PLATE 1
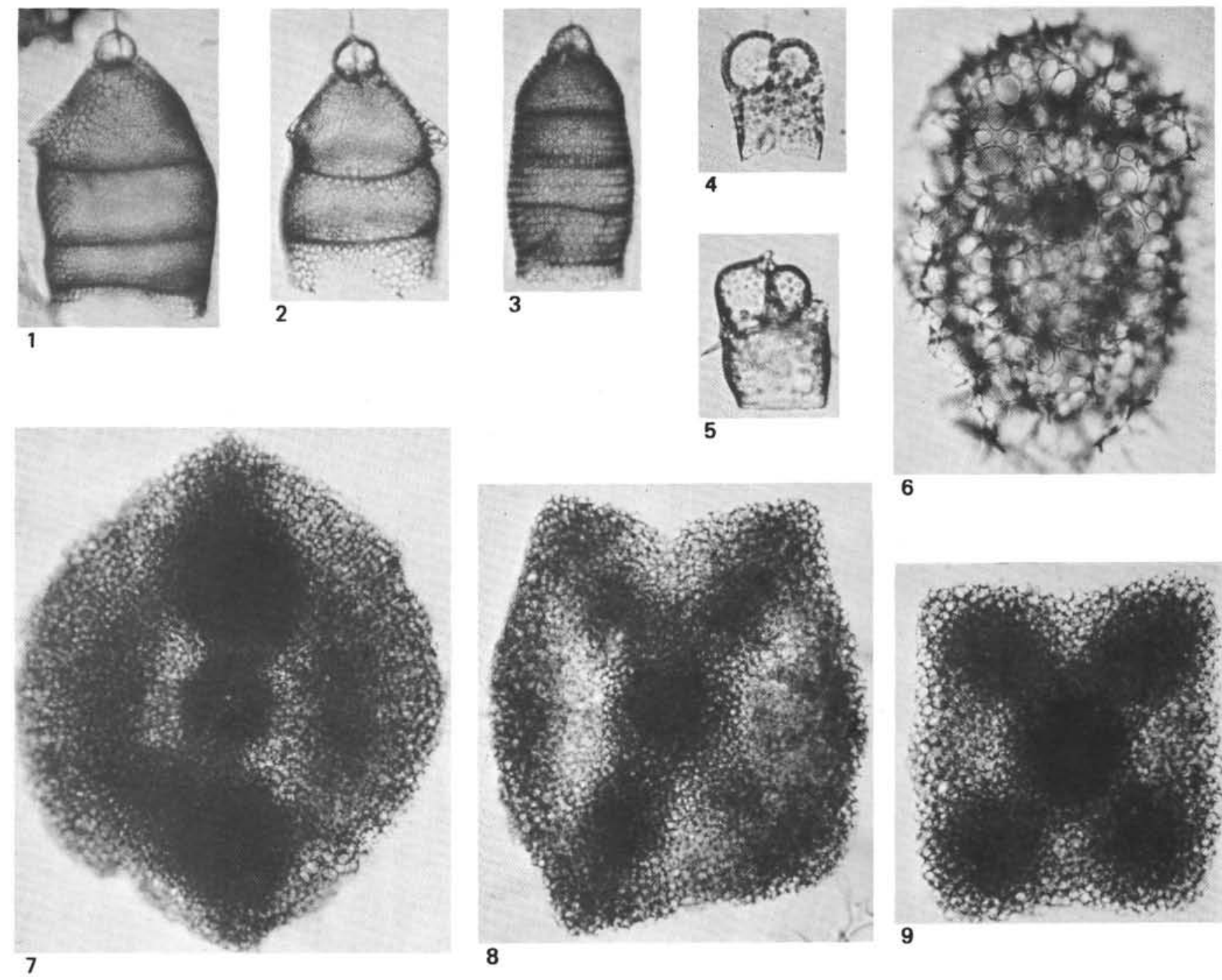

6

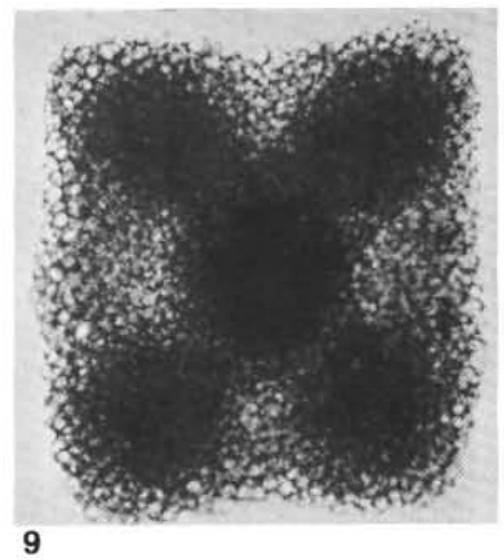

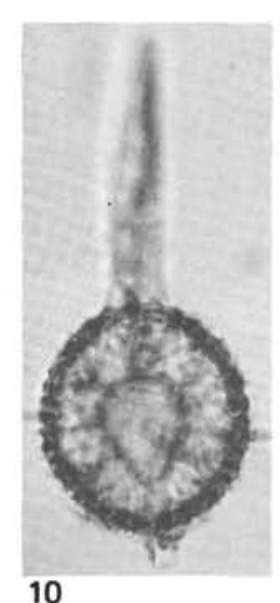

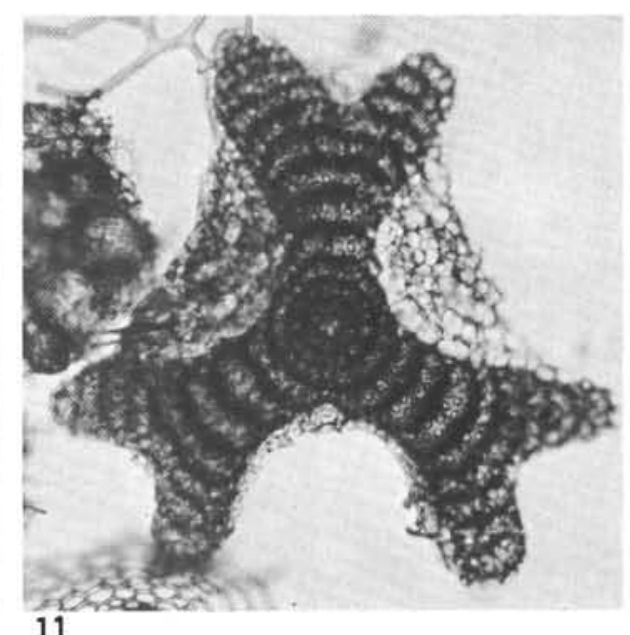

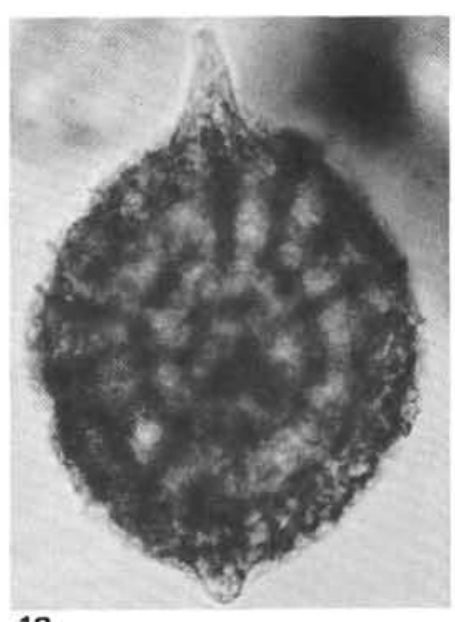

12

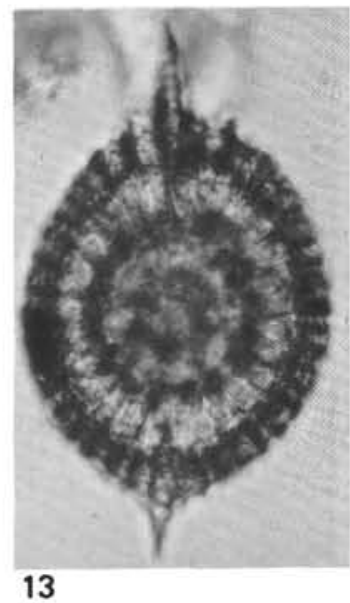

13 